\title{
SOCIAL MEDIA AND GENERATION Y, Z - A CHALLENGE FOR EMPLOYERS
}

\author{
Aneta KARASEK ${ }^{1}$, Beata HYSA ${ }^{2 *}$ \\ ${ }^{1}$ UMCS, Faculty of Economics; aneta.karasek@umcs.pl, ORCID: 0000-0002-6055-5150 \\ ${ }^{2}$ Silesian University of Technology, Faculty of Organization and Management; beata.hysa@polsl.pl, \\ ORCID: 0000-0003-1192-9395 \\ * Correspondence author
}

Purpose: The aim of this article is to identify the challenges that employers face when it comes to the use of social media (SM) at work in the context of expectations of future Generation $\mathrm{Y}$ and $\mathrm{Z}$ employees.

Design/methodology/approach: A critical analysis of literature of the subject, research results and reports analysis.

Findings: Literature as well as documents and reports analysis will allow to answer the following research questions: How important are social media for Generation $\mathrm{Y}$ and $\mathrm{Z}$ ? What are the preferences and expectations of Generation $\mathrm{Y}$ and $\mathrm{Z}$ when it comes to future employers in terms of use of modern information technologies and social media at work? In what areas employers are currently using social media? What changes are necessary in human resources management to motivate and maintain Generation $\mathrm{Y}$ and $\mathrm{Z}$ employees?

Originality/value: This study indicated the challenges that employers face when it comes to the use of social media (SM) at work in the context of expectations of future Generation Y and $\mathrm{Z}$ employees. From among these challenges, the authors paid attention to the need to increase the level of use of social media when it comes to employee management, the ability to create a positive company image in the social media and use these media to verify information on candidates applying for positions.

Keywords: Generation Y, Generation Z, social media, ICT, HRM.

Category of the paper: Research paper.

\section{Introduction}

Dynamically developing modern information technology, along with mobile communication, has significantly changed the functioning of modern organizations in all of their areas. In literature of the subject, one can find numerous researches concerning the influence of information and communication technologies (ICT) on the human resources management (HRM) in an organization (Piabuo et al., 2017; Rohilla 2015; Saberi, \& Khademi, 
2015). Moreover, along with the development of modern information technologies, what is changing is also the profile of required competences on the labour market (Morley et al, 2015; Ratti et al. 2016; Zdonek et al. 2017). More and more often, the organizations introduce new recruitment channels, the existence of which was forced by the appearance of the younger generation on the market, due to the fact that their natural communication and cooperation channels are social media. Managers responsible for employee management and such departments as Human Resources (HR) must deal with changes and different expectations of the new generation of employees (Lyons et al. 2015; Zabell et al., 2016, Fratričová \& Kirchmayer, 2018). In particular, what differs are the priorities and expectations of Generation $\mathrm{Y}$ and $\mathrm{Z}$ employees. This often makes it difficult for employers to find and maintain employees with relevant competences and high level of motivation.

Use of ICT in employee management is linked with multiple benefits for the organization (Kaur et al. 2014), but there are also certain threats. In particular, these threats concern functioning and communication of employees in social media (Kluemper et al., 2016; Hysa et al., 2015). Quite often, employees are not aware what kind of information is worth sharing and what should not be published in social media. This problem applies frequently to Generation $\mathrm{Y}$ and $\mathrm{Z}$ that are on the onset of their carrier and that treat social media as their basic communication channel. Moreover, social media in Poland became popular only a couple years ago; therefore, there are little empirical studies exploring this subject.

The aim of this article is to identify the challenges that employers face when it comes to the use of social media (SM) at work in the context of expectations of future Generation $\mathrm{Y}$ and $\mathrm{Z}$ employees. Literature as well as documents and reports analysis will allow to answer the following research questions: How important are social media for Generation $\mathrm{Y}$ and $\mathrm{Z}$ ? What are the preferences and expectations of Generation $\mathrm{Y}$ and $\mathrm{Z}$ when it comes to future employers in terms of use of modern information technologies and social media at work? In what areas employers are currently using social media? What changes are necessary in human resources management to motivate and maintain Generation $\mathrm{Y}$ and $\mathrm{Z}$ employees?

\section{Expectations, preferences and approach to work of Generation $Y$ and $Z$}

Assuming that a generation is a group of people sharing similar date of birth and important historical, cultural or social backgrounds, currently we can identify 4 generations of people being active in the Polish labour market (Wiktorowicz, 2018). These are Baby Boomers (born 1945-1964), Generation X (born 1965-1980), Generation Y (1981-1994) and Generation Z (born after 1995). Unfortunately, researchers cannot reach unanimity when it comes to defining the age range of generations, and Generation $\mathrm{Z}$ seems to be the most difficult to define. For example, Wiktorowicz (2018, p. 998) indicates that Generation Z starts in 1990, 
while McCrindle (2014, p. 12), Bencsik et al. (2016, p. 92) and Dolot (2018a, p. 44) claim that Generation Z starts after 1995. Additionally, more and more often researchers define a new generation, Generation Alpha, which started after the year 2000 and will soon enter the labour market (McCrindle, 2014; Dolot, 2018a). Each generation has different expectations, needs and approach to work and co-workers. This article focuses on Generation $\mathrm{Y}$ and $\mathrm{Z}$, as these generations are most frequently described as being difficult to manage and motivate.

Table 1 presents the characteristics of Generation $\mathrm{Y}$ and $\mathrm{Z}$, their motivations, expectations, approach to co-workers and employers. Moreover, it describes the importance of modern technology and social media for these generations.

Table 1.

Characteristics of Generation $Y$ and $Z$

\begin{tabular}{|c|c|}
\hline \multicolumn{2}{|c|}{ Characteristic features } \\
\hline Generation Y & Generation $\mathbf{Z}$ \\
\hline $\begin{array}{l}\text { realists, curious, with strong sense of freedom, } \\
\text { expect quick results, } \\
\text { have high perception of self-worth, } \\
\text { are characterized by divisibility of attention, } \\
\text { quite often they do not recognize authority of their } \\
\text { supervisor - what counts are their competences, }\end{array}$ & $\begin{array}{l}\text { they possess the ability of multitasking, } \\
\text { they are impatient, need quick feedback from } \\
\text { their supervisors, } \\
\text { they are resourceful, } \\
\text { open to the world and multiculturalism, }\end{array}$ \\
\hline \multicolumn{2}{|c|}{ Motivation and expectations } \\
\hline $\begin{array}{l}\text { they expect a well-paid job, } \\
\text {. they have huge expectations when it comes to their } \\
\text { career development, } \\
\text {. they expect flexible forms of employment, } \\
\text {. they require work-life balance, } \\
\text {. they expect quick career and promotion, }\end{array}$ & $\begin{array}{l}\text { they look for job in country and abroad, } \\
\text { they are resourceful, able to fulfil many roles, } \\
\text { they expect varied and interesting } \\
\text { responsibilities, competitive salary and } \\
\text { personalized development programs, } \\
\text { they want to establish their own business, }\end{array}$ \\
\hline \multicolumn{2}{|c|}{ Approach towards employer and co-workers } \\
\hline $\begin{array}{l}\text { less loyal to employers than the previous generations, } \\
\text { change of work is a part of their everyday lives - } \\
\text { significant professional mobility, } \\
\text { they possess the ability to adapt and are open to } \\
\text { change, }\end{array}$ & $\begin{array}{l}\text { they cherish new challenges and new methods } \\
\text { of management, } \\
\text { they prefer changes and are open to play many } \\
\text { functions in an organization, } \\
\text {. good relations are important for them, }\end{array}$ \\
\hline \multicolumn{2}{|c|}{ Importance of ICT and SM } \\
\hline $\begin{array}{l}\text { they are proficient users of digital technology } \\
\text { and ICT tools, } \\
\text { they live in a world of varied social media, }\end{array}$ & $\begin{array}{l}\text { they were raised in times of digital technology } \\
\text { and ICT tools, } \\
\text { they cannot function without the Internet and } \\
\text { mobile technology, } \\
\text { they actively participate in social media, }\end{array}$ \\
\hline
\end{tabular}

Source: own study based on: McCrindle, (2014); Dolot, (2018a); Ceglarz, (2017); Grenčíková \&Vojtovič, (2017); Lyons et al. (2017).

Generation Y, or Millennials, is a group of people who are quick in finding information, create communities, enjoy quick communication, have a need to surround themselves with electronics (Stosik \& Leśniewska, 2015) as, since childhood, they have been using mobile technology (mobile phones, tablets, iPods). Their main values are independence, ambition, creativity, innovation and development. They are characterized by flexibility greater than the flexibility of their predecessors and are open to change, ready to learn and unwilling to participate in long-term commitments. Moreover, Generation $\mathrm{Y}$ is less loyal towards their 
employers than the previous generations. They can be engaged in their work if it meets their expectations and needs, as well as leads to self-development. They have very high expectations towards their employers, which is associated with their strong sense of value. They often require control and support of managers when it comes to solving problems, as they are not as independent as their predecessors (Stosik, \& Leśniewska, 2015). Their weaknesses include low work ethics, lack of patience and self-discipline, as well as weaker decision-making abilities, high number of claims and difficulty in direct contacts with co-workers and employers.

Generation Z is also referred to as Generation C (as in "connected”), iGeneration, Gen Tech, Digital Natives, always clicking (Dolot, 2018). For Generation Z, virtual world and real world are the same reality. They cannot function without the Internet and electronic media. They look for diversity, run away from routine, they are willing to communicate with other cultures, travel abroad to learn languages and work. They are able to do many things at the same time, but it is difficult for them to focus on one activity. They know how to find the information they need quickly, but they are not always able to select and use it in practice. Although the representatives of Generation $\mathrm{Z}$ share many traits with the representatives of Generation Y, researchers (Ceglarz, 2017; Grenčíková, \& Vojtovič, 2017; Lyons et al., 2017) agree that, although some traits are more visible, still in many ways Generation $\mathrm{Z}$ differs significantly from their predecessors. Representatives of Generation $Z$ expect from their employers varied and interesting tasks, as well as personalized development programs, but in return they are ready to work hard and can stay in a company for longer. Millennials care about work-life balance. Generation $\mathrm{Z}$ goes further, expecting work-life integration. This means the end of the division between private and professional life - work can become an extension of private life and can be a pleasure, not a constraint. Yet, for the work to be a pleasure for them, the employers must take care about the diversity of tasks. Another way that distinguishes Generation $Y$ from Generation $\mathrm{Z}$ is the manner of working. Millennials prefer teamwork, while Generation Z prefers to work independently, ambitiously, when they can compete with one another. What Generation $\mathrm{Y}$ and $\mathrm{Z}$ have in common is the fact that they feel at ease in the world of new technology and expect to find work that makes use of it. In the future, they will have no problems with working with robots or AI. They are also very natural when it comes to job interviews with the use of Internet, for example via Skype. In turn, Generation $Z$ is more resourceful and is more willing to declare that they will decide on self-employment.

The biggest difference between young Generation $\mathrm{Y}$ and $\mathrm{Z}$ and older generations is their approach to ICT and social media. They cannot imagine functioning without virtual world and mobile technologies. The manner of living and communication of Generation $\mathrm{Y}$ and $\mathrm{Z}$ forces the managers to provide daily feedback, as these generations are multi-tasking oriented. The representatives of Generation $Z$ are constantly collecting and verifying necessary information that they share with others. They communicate with each other using such applications as WhatsApp, social media, they comment the reality and the surrounding world 
(Twitter, blogs, message boards), they share pictures (Instagram, Pinterest, Snapchat) and films (Instagram, YouTube, Snapchat).

According to Deloitte report (2018), the main factors that Generation Y and Z take into account when looking for a new job are financial aspects $(61 \%$ Millennials, $51 \%$ Gen Z), positive culture of the workplace (52\% Millennials, $57 \%$ Gen Z), flexibility (50\% Millennials, $44 \%$ Gen Z) and the possibility of constant learning (48\% Millennials, 44\% Gen Z).

\section{Social media in employee management}

New generations of employees are entering the labour market, along with high expectations towards employers. In order to increase the effectiveness of their activities in terms of sourcing employees from younger generation, employers introduce IT solutions in various areas of employee management. Social media are one of such solutions, meaning a range of Internet applications, based on ideological and technological foundations of Web 2.0, making it possible to create and share content generated by users (Kaplan, and Haenlein, 2010, pp. 61). At first, social media were used mainly in the area of marketing, sales, customer services or managing customer relations. However, with time, they began to be used in communication inside the organization, for the purpose of cooperation or generation of ideas in the so-called open innovation model. Currently, social media are more and more often used in recruitment, employee selection, competitiveness development or knowledge management.

A.M. Kaplan and M. Haenlein proposed a wide classification of social media, where of interest is the self-presentation/social dimension within which they included (Kaplan, and Haenlein, 2010, p. 62):

- high self-presentation/social dimension, which include blogs, social networking sites (e.g. Facebook), virtual social worlds (e.g. Second Life),

- low self-presentation/social dimension, which include collaborative projects (e.g. Wikipedia), content communication (e.g. YouTube) and virtual game worlds (e.g. World of Warcraft).

Currently, in Poland we can observe an increase of the use of SM by the society. In January 2019, in Poland there were 18 million active social media users, which constitutes $47 \%$ of population, and from the beginning of the year their numbers increased by 1 million (Digital Poland, 2019). In 2017, 63\% used social networks in the last 3 months, which ranks Poland on the 22nd place among 28 EU countries (DESI, 2018, p. 8). On average, everyday Poles spend $1 \mathrm{~h}$ and $45 \mathrm{~min}$ in social media, most often YouTube, and the second most popular website is Facebook, the average monthly traffic of which amounts to 13 minutes and 22 seconds (Digital Poland, 2019). We can observe an increase in number of social media users, while professionally they are used only by $17 \%$ of users (Digital Poland, 2019). From among 
social media users (Figure 1) the most numerous group is Generation Y (aged 25-34) and Generation Z (aged 18-25).

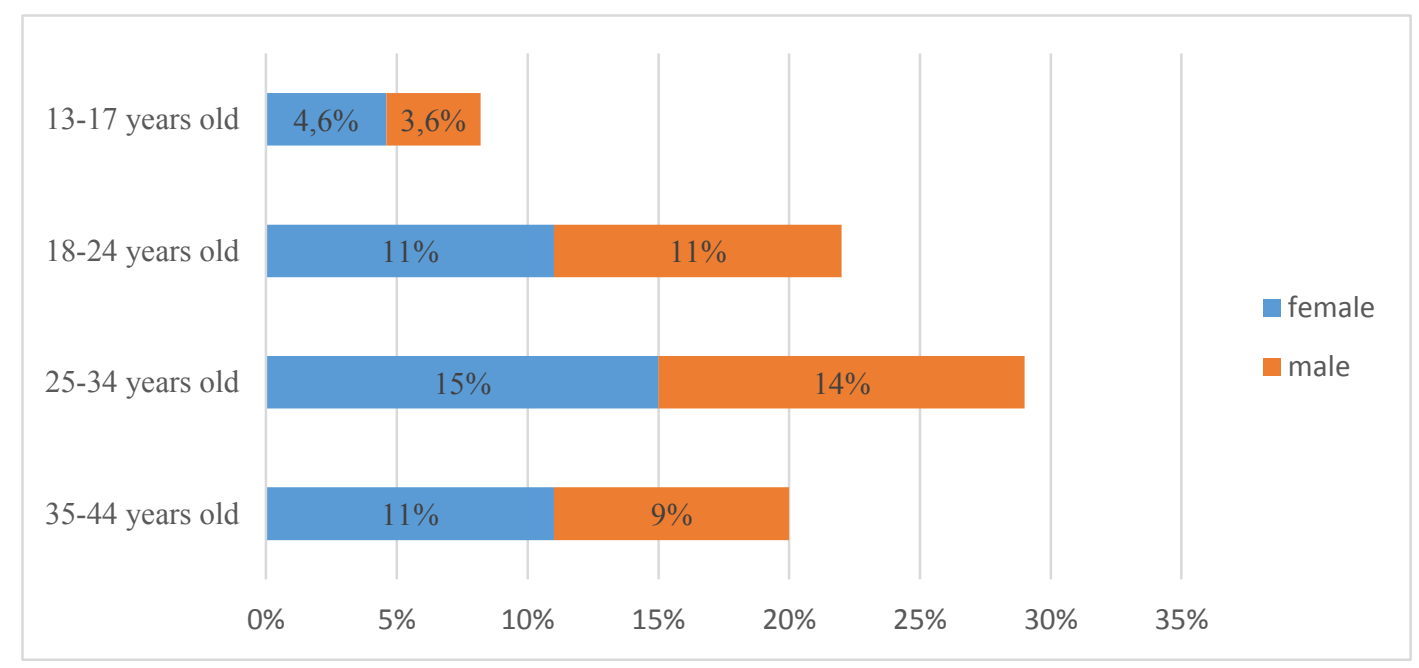

Figure 1. Social media audience profile (based on the combined advertising audiences of Facebook, Instagram and Facebook Messenger). Source: own study based on: Digital 2019: Poland, https://datareportal.com/reports/digital-2019-poland, 3.06.2019.

Therefore, it seems that an important communication channel between employers and young generation of employees will be social media. According to research carried out by Randstad and Future, $41 \%$ of young people want to incorporate social media in their workplace (Future Workplace and Randstad, 2016). Moreover, 41\% of Millennials and Gen Z indicated a quick need of social media incorporation, while $18 \%$ declared the incorporation of Massive Open Online Courses (MOOCs) (Future Workplace and Randstad, 2016). However, only 10\% of enterprises use social media, as a result of which Poland ranked 26th out of $28 \mathrm{EU}$ member states (DESI 2018, p. 10). Due to the expectations of Generation Y and Z and low use of social media in enterprises, it can indicate a huge challenge for employers in this scope. To meet the expectations of Generation $\mathrm{Y}$ and $\mathrm{Z}$, it is, therefore, necessary to introduce such solutions that use social media in employee management.

Literature overview indicates a range of possibilities when it comes to use of social media in employee management and establishing a positive image of the employer. Due to a wide range and speed of information spreading, it is possible to share information with a wide range of recipients and to create interest groups. It is through social media that enterprises take on activities to influence job applicants. Social media allow organizations to weave complex visual, auditory, and cognitive recruitment messages that are broadly distributed (Kluemper et al., 2016). Shared messages can encourage potential employees to apply and influence the image of the employer as perceived by Generation Y and Z. It is well-known that the more varied stimuli and visual effects, the easier it is to influence the beliefs of others (Kluemper et al., 2016). Enterprises use both the websites and social media to inform about the recruitment. However, research results indicate that, for younger applicants, frequently updated websites and interactive functions in social media convince them to apply faster, than only statistical 
browsing of the enterprise website (Intindola et al., 2017). As a result, for enterprises it seems important to use social media as means of conveying image that encourages young employees to apply.

Employers use social media in the process of selection, which allows them to verify job applicants. Research carried out among 202 recruiters stated that $37 \%$ of them uses social media to "screen" a potential employee (Alexander et al., 2019). Due to the fact that young employees are prone to publish personal information in social media, for employers it is a valuable source of information. Therefore, another challenge for employers is a skilful use of information source, that is social media, for candidate verification and for the decision making process.

A trait that is characteristic of Generation $\mathrm{Y}$ and $\mathrm{Z}$ is readiness for change and constant lookout for new development possibilities, therefore, employers find it difficult to keep a valuable employee and motivate them to work. As indicated by research (Naim, Lenka, 2018), one of the elements allowing to keep and develop Generation Y employees are social media. Moreover, 19\% of Millennials and Generation $\mathrm{Z}$ working in companies achieving high results indicate, that allowing for the use of social media to cooperate and communicate engages them in better work performance (Future Workplace and Randstad, 2016). Therefore, one can indicate that for younger generations the use of social media at work may help develop their competences and keep them in the organization for longer. It is a valuable tip for employers interested in keeping valuable employees.

Social media give the opportunity of constant availability and effective communication, which fosters engagement in duties performance. In turn, research carried out among employees using SM at work (Zoonen, Verhoeven, Vliegenthart, 2017, pp. 602) indicate that this availability and effortless contact with diverse social groups causes downtime and conflicts associated with lesser balance between professional and personal life. These solutions engage employees to a large extent, which causes low level of control of time they spend in social media and decreases their engagement in the task being currently implemented. Currently, $33.2 \%$ of Polish teenagers are worried that they spend too much time online (Klingemann, Sierosławski, 2018, pp. 97). In turn, 46\% of respondents from both generations claimed that social media with text information are the most distracting technology (39\%). It is similar with email (31\%) (Future Workplace and Randstad, 2016). Therefore, a challenge for the employers is to ensure a work-life balance when using social media to make sure that it will not decrease the engagement of employees and their effectiveness in implementing tasks.

A range of expectations on the part of future employees when it comes to the use of social media by future employers was presented, which can be beneficial for both parties but can also be a threat. Young people are worried that their activity and information they share about themselves may have a negative influence on their career, while employers are afraid of leak of information on the enterprise, spying and cyberactivity. In order to solve this problem, a dialog and implementation of general rules concerning the use of social media at work are proposed (Opgenhaffen, Claeys, 2017). Therefore, a challenge that employers have to face is to establish 
general rules on the use of social media at work, implement security measures and define which information and data can be shared in the social media and which cannot.

\section{Discussion and summary}

Various values held by employees concerning their personal and professional lives influence their approach to work, behaviours and motivation. Being aware of the values of the employees, their preferences and expectations can help employers in establishing work organization systems, motivation, creation of career paths, establishing enterprise strategy, creation of organizational culture, etc. Currently, it is difficult for the employers to keep and motivate Generation Y and Z. Their everyday functioning in the world of modern technologies and social media forced employers to open themselves to a different type of management, cooperation and communication. Even though employers more and more often use social media to create a positive company image, they still have to face a lot of challenges in the recruitment process or in communication.

The most important challenges that employers face when it comes to the use of social media (SM) at work in the context of expectations of future Generation $\mathrm{Y}$ and $\mathrm{Z}$ employees are as follows:

- Increase of the level of use of social media in employee management.

- Skilful creation of a positive company image in social media.

- Use of social media to verify information on applicants and make a decision concerning their employment.

- Use of social media for communication and cooperation with representatives of Generation $\mathrm{Y}$ and $\mathrm{Z}$ to increase their engagement in work and keep them in organization.

- Skilful assurance of work-life balance when using social media.

- Establishment of relevant policy on social media use, security rules and protection against disclosure of confidential information.

Critical analysis of literature has shown that for Generation $\mathrm{Y}$ and $\mathrm{Z}$ it is very important to use modern technologies and social media at work, and enterprises are not yet fully prepared for that to happen. This article presents the research results to-date in this scope that allowed to indicate main challenges faced by employers. In their further research, the authors want to explore the subject through empirical studies, both among Generation Y, Z and Alpha employees, as well as among employers. 


\section{References}

1. Alexander, E.C., Mader, D.R.D., Mader, F.H. (2019). Using social media during the hiring process: A comparison between recruiters and job seekers. Journal of Global Scholars of Marketing Science, 29, 1, pp. 78-87, https://doi: 10.1080/21639159.2018.1552530.

2. Bencsik, A., Horváth-Csikós, G., Juhász, T. (2016). Y and Z Generations at Workplaces. Journal of Competitiveness, 8, 3, pp. 90-106, https://doi.org/10.7441/joc.2016.03.06.

3. Ceglarz, J. (2017). Pokolenie Z wchodzi na rynek pracy. Są zdecydowanie inni niż ich starsi koledzy. Retrieved from: https://praca.money.pl/wiadomosci/artykul/pokolenie-z-rynekpracy, 152,0,2348696.html, July 2019.

4. Deloitte Millennial Survey 2018. Retrieved October 3, 2018. Available at: https://www2.deloitte.com/content/dam/Deloitte/sk/Documents/Publikcie/gx-2018millennial-survey-report\%20(1).pdf.

5. Digital 2019: Poland. Retrieved from: https://datareportal.com/reports/digital-2019-poland, 3.06.2019.

6. Dolot, A. (2018). Proces poszukiwania pracy przez młode pokolenie - wybrane zagadnienia - wyniki badań empirycznych. Studia Ekonomiczne, 359, pp. 284-299.

7. Dolot, A. (2018a). The characteristics of Generation Z. E-mentor, 2(74), pp. 44-50, Warsaw: School of Economics.

8. Fratričová, J., Kirchmayer, Z. (2018). Barriers to work motivation of generation Z. Journal of Human Resource Management, XXI, 2, pp. 28-39.

9. Gen $Z$ and millennials collide at work, Despite the tech revolution, Gen $Z$ and Millennials crave in-person collaboration (2016). Future Workplace and Randstad, Retrieved from: https://workplacetrends.com/wp-content/uploads/2017/07/Gen-Z-and-Millennials-Collideat-Work-Final.pdf, 3.06.2019.

10. Grenčíková, A., Vojtovič, S. (2017). Relationship of generations X, Y, Z with new communication technology, Problems and Perspectives in Management, 15, 2, p. 558-564, https://doi.org/10.21511/ppm.15(si).2017.09.

11. Hysa, B. Mularczyk, A., Zdonek, I. (2015). Social media - the challenges and the future direction of the recruitment process in HRM area. Studia Ekonomiczne, 234, Katowice: Uniwersytet Ekonomiczny, pp. 54-67.

12. Intindola, M.L., Lewis, G., Flinchbaugh, C., Rogers, S.E. (2017). Web-based recruiting's impact on organizational image and familiarity: too much of a good thing? The International Journal of Human Resource Management, https:/doi: 10.1080/ 09585192.2017.1332672.

13. Kaplan, A.M., Haenlein, M. (2010). Users of the world, unite! The challenges and opportunities of Social Media. Business Horizons, 53, pp. 59-68. 
14. Kaur, M., Sindhu, L.S., Sharma, S., Narang, S. (2014). Information Technology in Human Resources Management: A Practical Evaluation. An International Journal of Advanced Computer Technology, 3, 12, pp. 1437-1442.

15. Klingemann, J.I., Sierosławski, J. (2018). Social media use among the youth. Results of the ESPAD study in Poland with reference to other European countries. Alcohol Drug Addict, 31(2), pp. 87-106, https://doi.org/10.5114/ain.2018.79942.

16. Kluemper, D.H., Mitra, A., Wang, S. (eds.) (2016). Social Media use in HRM. Research in Personnel and Human Resources Management, 34, Emerald Group Publishing Limited, pp. 153-207.

17. Lyons, S.T., Schweitzer, L. Ng, E.S.W. (2015). How have careers changed? An investigation of changing career patterns across four generations. Journal of Managerial Psychology, 30, 1, pp. 8-22.

18. McCrindle, M. (2014). The ABC of XYZ: Understanding the global generations. Australia: McCrindle Research Pty Ltd A39.

19. Morley, S., Cormican, K., Folan, P. (2015). An Analysis of Virtual Team Characteristics A Model for Virtual Project Managers. Journal of Technology Management \& Innovation, 10, 1, https://doi.org/10.4067/S0718-27242015000100014.

20. Opgenhaffen, M., Claeys, A.-S. (2017). Between hope and fear: developing social media guidelines. Employee Relations, 39, 2, pp. 130-144, https://doi.org/10.1108/ ER-04-20160086.

21. Piabuo, S.M., Piendiah, N.E., Njamnshi, N.L. et al. (2017). The impact of ICT on the efficiency of HRM in Cameroonian enterprises: Case of the Mobile telephone industry. Journal of Global Entrepreneurship Research, https://doi.org/10.1186/s40497-017-0063-5.

22. Ratti, C., \& Claudel, M. (2016). If work is digital, why do we still go to the office? Harvard Business Review Digital Articles.

23. Rohilla, J. (2015). Role of Information Technology in Human Resources Management. International Journal of Advance Research, Ideas and Innovations in Technology, 3, 2, pp. 566-569.

24. Saberi, A., Khademi, B. (2015). Explaining the Role of Information Technology in Human Resource Development (CaseStudy: Staff and Faculty Members of Islamic Azad University, Darab). International Journal of Economy Management and Social Science, 4(1), pp. 67-74.

25. Stosik, A., Leśniewska, A. (2015). Innowacyjne rozwiązania w zarządzaniu zasobami ludzkimi - perspektywa adaptacji i różnic pokoleniowych. Studia i prace Wydziału Nauk Ekonomicznych i Zarzadzania, 39, 3. Szczecin: Wydawnictwo Naukowe Uniwersytetu Szczecińskiego, pp. 183-196.

26. Wiktorowicz, J. (2018). The situation of generations on the labour market in Poland. Economic and Environmental Studies, 18, 2, pp. 995-1015. 
27. Zabell, K.L., Benjamin, B.J., Biermeier-Hanson, B.B., Baltes, E.B.J., Shepard, A. (2016). Generational Differences in Work Ethic: Fact or Fiction? Journal of Business and Psychology Science Business Media, New York: Springer.

28. Zdonek, I., Podgórska, M., Hysa, B. (2017). The competence for project team members in the conditions of remote working. The Journal of Warsaw University of Technology, Foundations of Management, 9, 1, pp. 213-224, https://doi.org/10.1515/fman-2017-0017.

29. Zoonen, W. van, Verhoeven, J.W.M., Vliegenthart, R. (2017). Understanding the consequences of public social media use for work. European Management Journal, 35, pp. 595-605. 